\title{
The Impact of Social Media on Employee Work Performance with Trust as a Mediation Variable
}

\author{
B. Medina Nilasari \\ Program Studi Magister Manajemen Universitas Trisakti \\ Email: medina@trisakti.ac.id
}

\begin{abstract}
Can the use of social media which is currently a trend in the community, have an influence on improving employee performance? This is what makes the research carried out. The analysis technique used is the Structural Equation Model (SEM) method with AMOS version 23. The sample consisted of 102 people who were employees in various types of private companies in DKI Jakarta. The results showed that the more social media is used to communicate with colleagues in completing work, the more trust among employee increases. Also the more social media is used to communicate with colleagues in completing work, the more improves employee work performance. But trust can not influence performance of employee, and trust is not a variable that mediates between social media and employee performance.
\end{abstract}

Keywords: Social Media, Trust, Employee Work Performance.

\begin{abstract}
Abstrak: Apakah penggunaan media sosial yang saat ini sedang trend di masyarakat, memberikan pengaruh terhadap meningkatnya kinerja karyawan? Hal inilah yang membuat penelitian dilakukan. Analisis dilakukan dengan metode Structural Equation Model (SEM) menggunakan program AMOS versi 23. Sampel berjumlah 102 orang yang merupakan karyawan di berbagai tipe perusahaan swasta di DKI Jakarta. Hasil penelitian menunjukkan bahwa semakin media sosial digunakan untuk berkomunikasi dengan kolega dalam menyelesaikan pekerjaan maka semakin meningkatkan trust diantara karyawan. Hasil penelitian juga memperlihatkan semakin media sosial digunakan untuk berkomunikasi dengan kolega dalam menyelesaikan pekerjaan maka semakin meningkatkan kinerja karyawan di tempat kerja. Namun tidak terdapat pengaruh trust terhadap kinerja karyawan, dan trust bukan variabel yang memediasi pengaruh media sosial terhadap kinerja karyawan.
\end{abstract}

Kata Kunci: Media Sosial, Kepercayaan, Kinerja Karyawan.

\section{INTRODUCTION}

The rapid development of technology and information has a big influence on the development of the current global situation. In fact, information technology always gives feedback, both positively and negatively to every aspect of life. The development of technology and information that is very popular in today's society is Social Media. Nowadays, social media has become a basic necessity for everyone. Social media networks that are often used include Facebook, Twitter, Telegram, Instagram, WhatsApp and others. 
Information technology has developed rapidly and made organizations adopt social media as a strategic tool used to communicate between employees within the organization, as well as between employees and parties outside the organization. To build social relationships, the human resources department uses enterprise social media. To improve communication and increase trust between employees, the human research department uses also enterprise social media. A study from (Alavi and Leidner, 2001); (Wasko and Faraj, 2005) shows using electronic networks is related to management of knowledge, communication, and collaboration that will improve people performance in the workplace (North, 2010).

The development of social media will certainly have a positive impact if it is managed carefully. There is a positive side to social media, namely: First, social media provides fast and accurate information. Various information can be obtained easily and quickly, namely information on public services, security problems, traffic jams, accidents and so on. That is why companies are now starting to socialize through social media, so that information about the organization can be known as soon as possible. Second, provide space for positive messages. Social media is now widely used by entrepreneurs, politicians, motivators, students, students and others as a means to publicize their various interests. Many positive things from information on social media, just sorting out the pros and cons according to the truth and conscience. Third, familiarizing friends. Social media has now bridged through groups built with various communities. Getting to know each other, sharing and sharing information will make the horizon of thinking broader. The fourth positive side, can strengthen friendship. Indonesia is an archipelagic nation and spread throughout the archipelago, in terms of friendship with family, friends and others who are quite far apart requiring cost, time and energy, thanks to the current social media services everything is easy and practical. Fifth, add insight and knowledge. Something that is not known and needs a quick answer, can be browsed on Google and in an instant the answer will appear.

Social media has revolutionized communication in human life with widespread applications and rapid growth (Chang and Hsiao, 2014). Social media has been used at work, helping communication and organizational knowledge that in the past was not possible (McAfee, 2006). With the success of social media, it motivates a strong interest in using social networks to improve communication in organizations. Previous research has provided into social media capabilities. However, social media at work still has pros and cons, still controversial. Social media having a negative reputation can reduce productivity and increase disruption. But positively, employees use social media not only to seek and disseminate information, but also as a medium of communication with friends, in order to gain belonging of sense and good relationship increases (Cao et al., 2016).

(Cao et al., 2016) argues the use of social media will encourage social capital of employees which then helps the transfer of knowledge. Social capital and knowledge transfer will be able to improve performance. Meanwhile, according to (Fang and Chiu, 2010), the use of enterprise social media build and improve social networking and interaction which ultimately leads trust between co-workers. It is hoped that organizations that adopt social media used by employees can increase trust among themselves. This study will seek answers to the following questions which are seen from employee's perpectives: is social media influence trust? Is social media affect employee work performance? Is trust affect employee work performance? Can trust as mediating variable between social media and performance of employee at work? 
Outcome of this study are expected to add insight into how social media affects employee performance, and can also provide input to organizations that Social Media can affect employee performance.

\section{THEORITICAL REVIEW}

Social Media. (Parveen et. al., 2016) states, social media has changed the way business is done. The statement from (Pride et al., 2017) is, social media represents the online interactions that allow people and businesses to communicate and share ideas, personal information, and information about products and services. According to (DiMicco et al., 2008), Employees use the internet with the main motivation is to build stronger ties (Network Ties) between employees and also to reach employees they don't know well. (Jackson et al., 2007) also fond out how useful blogs at work is to create, maintain and strengthen relationships. At companies like IBM and Microsoft, young and new employees will be familiar with Facebook. This social media is used extensively to learn about their new colleagues and also create new social relationships (DiMicco et al., 2008). Social media is an effective platform that consists of a collection of information and tools of communication. Social media provides a variety of channels in communication, both in environment of work and the social (Cao et al., 2016). Employees use social media to search and share information, also to meet friends. They use social media to obtain and develop relationship among people (Cao et. al., 2016). (Smith, 2009) states that the independence of space on social media creates open communication that gives rise to a new form of collaboration, where users can share at any time without time and location restrictions. Users interact with various levels of intensity on an unprecedented scale. Using social media also influence of organizational performance, with the most dominant social media usage elements being on 'social media for information accessibility' (Nilasari et. al., 2019).

Trust. An individual's ability to authenticate knowledge that is accepted as relevant and factual, without risk, without error and inconsistency, is known as a trust (Lin, 2007). (Skinner et al., 2014) stated, trust is a "process" from individual beliefs which focus and lead to decisions to believe and show trust. In general, trust grows over time with interactions, relationships and experiences (Fang and Chiu, 2010). Deep understanding can minimize the behavior of uncertainty and intentions of others, as a prerequisite for trust (Valenzuela et al., 2009). Recognize other people more, will believe (trust) or the more will not believe (distrust). Individual trust (trust) can be obtained through communication in various kinds of media, one of them is social media (Cao et al., 2016). Many studies of trust between employees and management have been conducted before (Kampkötter et al., 2016). Studies (Weibel et al., 2016) has also examined about organizations which is try to organize behavior of employee as a way to improve employee confidence in organizations. The important thing in terms of knowledge transfer is trust between employees. The focus of interpersonal trust is on individuals who are willing to be vulnerable and believe in the positive behavior of their peers (De Jong et al., 2016). (Fang and Chiu, 2010) stated, interaction of face to face, mutual experience, and length of intimacy will lead to ready and willing in transfer knowledge. (Cao et al., 2016) argues, employee social capital can be driven by social media, which also facilitates the transfer of knowledge. Improving employee performance can be helped by social capital and knowledge transfer. (Fang and 
Chiu, 2010) discusses many studies and theories which state that trust has a positive effect on the intention to share individual knowledge and behavior in organizations.

Employee Work Performance. In the view of (Halabi and Lussier, 2005), performance is an expansion in which expectations or objectives have met. As according to (Hariandja, 2004), performance is defined as the results of work produced by employees or actual behavior that is displayed in accordance with its role in the organization. Whereas (Tika, 2010) states that company performance is the result of the work function or activities of a person or group of people in an organization which is influenced by various factors for the achievement of organizational goals at a certain period of time. If indicators used as performance measures increase, the strategy has been implemented well (Anthony and Govindarajan, 2001). Based on description above it can be stated, that good performance of employee is a step to achieve organizational goals.

Figure 1. Conceptual Framework

(Fang and Chiu, 2010)

(Cao et al., 2016)

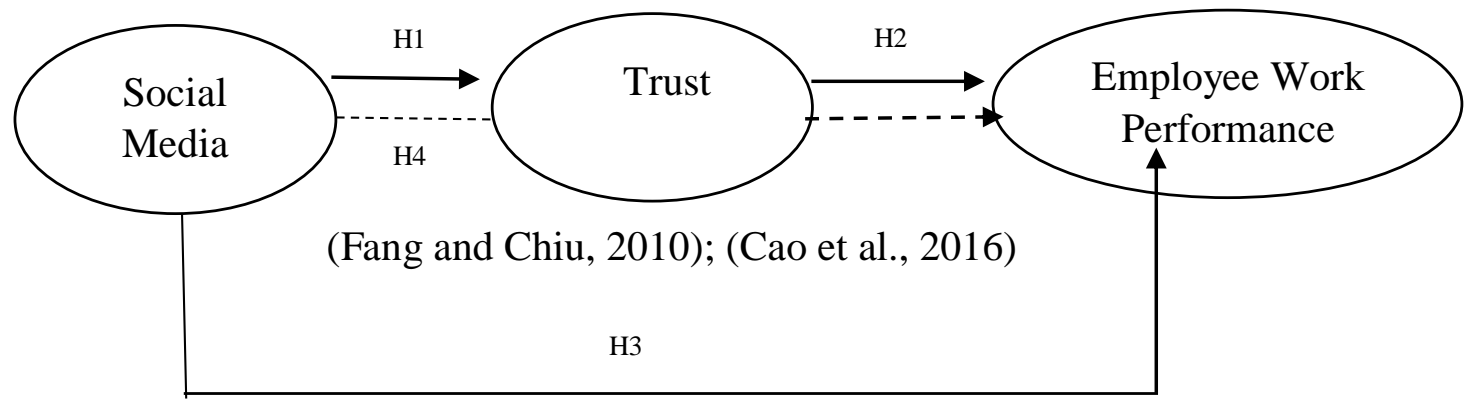

(Leidner et al., 2010)

Hyphotesis. The use of Enterprise Social Media (ESM) can increase interactivity and create social networks that can create trust among colleagues (Cao et al., 2016). The study of virtual teams and the distribution of work found that trust is positively related to knowledge transfer. This shows that understanding through the use of ESM and reciprocal communication will increase interpersonal trust in virtual team members (Chen and Hung, 2010). Hopefully the successful adoption of ESM by employees will enable organizations to increase trust among them. Based on previous research, the first hypothesis can be arranged as follows:

H1: Social Media influences Trust among employees.

Knowledge is the main competitive advantage for every individual and even organization. (Stasser and Titus, 1985) said that the transfer of knowledge that is often done will be able to provide a way to solve problems, which helps in making superior decisions. (Andres and Zmud, 2002) also stated that increased knowledge exchange would be very important to overcome interdependence of task and uncertainty. (Cao et al., 2016) argue that trust based on the transfer of knowledge on social media has increased the ability of 
employees to solve problems effectively, and eventually will improve work performance. Based on previous research, the second hypothesis can be arranged as follows:

H2: There is an influence of Trust on Employee Work Performance.

Social media influences employee performance. Previous research from (North, 2010) supports this statement that the use of social media in the workplace is beneficial, enabling the realization of new relations also maintaining existing one. Research (Leidner et al., 2010) showed that by using ESM, new employee performance will be faster and better, by increasing new relationships and transferring knowledge tacit and explicitly. The use of ESM will increase collective knowledge so that it contributes to employee job performance (Bennett et al., 2014). Based on previous research, the third hypothesis can be arranged as follows:

H3: Social Media influences Employee Work Performance.

(Fang and Chiu's, 2010) research shows that the use of Enterprise Social Media (ESM) can create and strengthen social networks and interactions that can create trust among colleagues. (Cao et al., 2016) argue that trust based on knowledge transfer on social media has increased the ability of employees to solve problems effectively, and eventually will improve work performance. Based on previous research, the fourth hypothesis can be arranged as follows:

H4: Trust as a mediation between the influence of Social Media on Employee Work Performance.

\section{METHODOLOGY}

Design of this research was a hypothesis test (hypotesis testing). Hypothesis testing is research that aims to test hypotheses and generally is research that explains phenomena in the form of relationships between variables. The time horizon of this study is cross-sectional meaning that information is collected only once even though it may be done for a certain period so that it is often known as one-shot (Sekaran and Bougie, 2010). One shot of this research at a certain time in January - March 2020.

Variables and Measurements. The research variable is an exogenous variable (independent variable) that is Social Media (Social Media Use at Work). Then the endogenous variable (dependent variable), namely Trust and Employee Work Performance, and Trust are also mediating variables. 
Table 1. Research Variables and Indicators

\begin{tabular}{|c|c|c|}
\hline Variable & Indicator & Sources \\
\hline $\begin{array}{l}\text { Social Media } \\
\text { (Social media } \\
\text { use at work) }\end{array}$ & $\begin{array}{l}\text { (1) I often use social media to obtain work-related information } \\
\text { and knowledge } \\
\text { (2) I regularly use social media to maintain and strengthen } \\
\text { communication with colleges in my work } \\
\text { (3) What is your frequency of usage of social media in the } \\
\text { work? }\end{array}$ & $\begin{array}{l}\text { Based on } \\
\text { (Kankanha } \\
\text { lli et al., } \\
\text { 2005) }\end{array}$ \\
\hline Trust & $\begin{array}{l}\text { (1) I assumed that members in the virtual community created } \\
\text { by social media would always look out for my interests } \\
\text { (2) I assumed that members in the virtual community created } \\
\text { by social media would go out of their ways to make sure I } \\
\text { was not damaged or harmed } \\
\text { (3) I felt like members in the virtual community created by } \\
\text { social media cared what happened to me } \\
\text { (4) I believed that members in the virtual community created } \\
\text { by social media approached their jobs with } \\
\text { professionalism and dedication } \\
\text { (5) Given members in the virtual community created by social } \\
\text { media track record, I saw no reason to doubt their } \\
\text { competence and preparation }\end{array}$ & $\begin{array}{l}\text { Based on } \\
\text { (Levin } \\
\text { and Cross, } \\
\text { 2004) }\end{array}$ \\
\hline $\begin{array}{l}\text { Employee } \\
\text { Work } \\
\text { Performance }\end{array}$ & $\begin{array}{l}\text { (1) I almost always perform better than an acceptable level } \\
\text { (2) I often perform better than can be expected from me } \\
\text { (3) I often put in extra effort in my work } \\
\text { (4) I intentionally expend a great deal of effort in carrying out } \\
\text { my job } \\
\text { (5) I try to work as hard as possible } \\
\text { (6) The quality of my work is top-notch }\end{array}$ & $\begin{array}{l}\text { Based on } \\
\text { (Kuvaas, } \\
\text { 2006) }\end{array}$ \\
\hline
\end{tabular}

Samples. The population of this research is employees who work in various types of private companies in DKI Jakarta. The number of samples is 102 people according to (Hair et al., 2014) that the recommended number of samples is in the range of 100 - 400. (Hair et al., 2014) also states that the minimum sample size is the number of indicators multiplied by 5 . The number of indicators of this study is 14 , multiplied by $5=70$ samples, therefore a total sample of 102 means that they meet the requirements.

Data Collection. Data were collected using a questionnaire technique, using an online questionnaire that can be accessed at:

https://docs.google.com/forms/d/e/1FAIpQLSf1J-

WJgGyuMduTSV8qvZNhuk_oYOrjfhiZBnnkWGLbGZ13LA/viewform?vc=0\&c=0\&w=1 This questionnaire is closed where the answer is already available. Questionnaire as a data collection tool using 5 Likert scale. Scale $1=$ Strongly Disagree until scale $5=$ Strongly Agree. 
Table 2. Characteristics of Respondents

\begin{tabular}{|c|c|c|c|}
\hline No. & Characteristics of Respondents & Amount & Persentage \\
\hline 1. & $\begin{array}{l}\text { Gender } \\
\text { Male } \\
\text { Female }\end{array}$ & $\begin{array}{l}49 \\
53\end{array}$ & $\begin{array}{l}48.0 \\
52.0\end{array}$ \\
\hline 2. & $\begin{array}{l}\text { Status } \\
\text { Married } \\
\text { Divorce } \\
\text { No Married }\end{array}$ & $\begin{array}{c}59 \\
1 \\
42\end{array}$ & $\begin{array}{c}57.8 \\
1.0 \\
41.2\end{array}$ \\
\hline 3. & $\begin{array}{l}\text { Age } \\
\qquad \begin{array}{l}\leq 21 \text { years } \\
>21-35 \text { years } \\
>35-45 \text { years } \\
>45-50 \text { years } \\
>50 \text { years }\end{array}\end{array}$ & $\begin{array}{l}1 \\
57 \\
18 \\
17 \\
9\end{array}$ & $\begin{array}{c}1.0 \\
55.9 \\
17.6 \\
16.7 \\
18.8\end{array}$ \\
\hline 4. & $\begin{array}{l}\text { Income } \\
\quad \leq \text { Rp. } 5.000 .000 \\
>\text { Rp. } 5.000 .000-\text { Rp. } 10.000 .000 \\
\text { >Rp. } 10.000 .000-\text { Rp. } 15.000 .000 \\
\quad>\text { Rp. } 15.000 .000\end{array}$ & $\begin{array}{l}18 \\
50 \\
10 \\
24\end{array}$ & $\begin{array}{c}17.6 \\
49.0 \\
9.8 \\
23.5\end{array}$ \\
\hline 5. & $\begin{array}{l}\text { Education } \\
\text { Diploma } \\
\text { Sarjana } \\
\text { Magister } \\
\text { Doktor }\end{array}$ & $\begin{array}{c}9 \\
69 \\
17 \\
7\end{array}$ & $\begin{array}{c}8.8 \\
67.6 \\
16.7 \\
6.9\end{array}$ \\
\hline 6. & 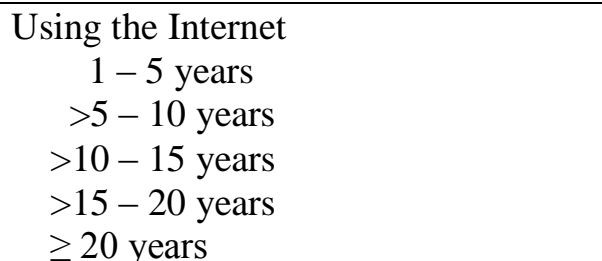 & $\begin{array}{c}2 \\
33 \\
39 \\
16 \\
12\end{array}$ & $\begin{array}{c}2.0 \\
32.4 \\
38.2 \\
15.7 \\
11.8\end{array}$ \\
\hline
\end{tabular}

Source: (Data Processing Results, 2020)

Test Reliability and Validity. Before a questionnaire which is an instrument in research is widely used first, it is tested to measure the validity and reliability of the measuring instrument. Validity and reliability tests in this study, using SPSS version 23 computer aids. Validity tests are used to measure the validity of a questionnaire. A questionnaire is said to be valid if the questions on the questionnaire are able to reveal something that will be measured by the questionnaire.

Table 3. Validity Test Results

\begin{tabular}{l|c|c}
\multicolumn{1}{c|}{ Variable } & Cooeficient & Decision \\
\hline Social Media & 0.667 & Valid \\
\hline Trust & 0.728 & Valid \\
\hline Employee Work Performance & 0.827 & Valid \\
\hline
\end{tabular}

Source: (Data Processing Results, 2020) 
Test Reliability with the "Internal Consistency Reliability Method", using the Cronbach's Alpha coefficient. Cronbach's coefficient alpha as a coefficient of reliability is used to test each construct. According to (Sekaran and Bougie, 2010), the closer the reliability coefficient is to 1 (one), the better it is considered. In general, reliability less than 0.6 is considered weak, around 0.7 is considered acceptable, while above 0.8 is considered good. Based on the statement above, the basis for making a reliability test can be concluded as follows:

(i) If the cronbach's coefficient alpha $\geq 0.6$, the construct is considered reliable.

(ii) If the cronbach's coefficient alpha $<0.6$, the construct is considered unreliable.

Table 4. Reliability Tests

\begin{tabular}{l|c|l}
\hline \multicolumn{1}{c|}{ Variable } & \multicolumn{1}{c|}{$\begin{array}{c}\text { Cronbach } \\
\text { Alpha }\end{array}$} & Decision \\
\hline Social Media & 0.755 & Reliable \\
\hline Trust & 0.851 & Reliable \\
\hline Employee Work Performance & 0.833 & Reliable \\
\hline
\end{tabular}

Source: (Data Processing Results, 2020)

Test of Goodness of fit. Goodness of fit evaluation is done to see to what extent the data and models meet SEM assumptions. Evaluation is carried out on the overall model then proceed with evaluation of the measurement and structural models separately (Hair et al., 2014). (Hair et al., 2014) states that from several Absolute Fit Measure and Incremental Fit Measure tests, if the results of one test are 'fit' then it can be concluded that the model used is fit.

Table 5. Goodness of Fit

\begin{tabular}{|c|c|c|c|c|}
\hline $\begin{array}{c}\text { Types of Goodness } \\
\text { of Fit }\end{array}$ & $\begin{array}{c}\text { Goodness of Fit } \\
\text { Measure }\end{array}$ & $\begin{array}{l}\text { Level of Acceptance } \\
\text { (Hair } \text { et al., 2010) }\end{array}$ & $\begin{array}{l}\text { Calculating } \\
\text { Measure }\end{array}$ & Acceptable \\
\hline \multirow{3}{*}{$\begin{array}{l}\text { Absolute } \\
\text { Fit Measure }\end{array}$} & Chi-square & Small chi-square & 138,321 & POOR FIT \\
\hline & $p$-value & $p$-value $\geq 0.05$ & 0.000 & POOR FIT \\
\hline & $R M S E A$ & $<0.10$ & 0.090 & GOOD FIT \\
\hline Incremental Fit & $R M R$ & $<0.10$ & 0.052 & GOOD FIT \\
\hline Measure & $N F I$ & $>0.90$ or close to 1 & 0.791 & POOR FIT \\
\hline & $T L I$ & $>0.90$ or close to 1 & 0.862 & MARGINAL \\
\hline & $C F I$ & $>0.90$ or close to 1 & 0.888 & MARGINAL \\
\hline Parsimonius Fit & $I F I$ & $>0.90$ or close to 1 & 0.891 & MARGINAL \\
\hline Measure & $\begin{array}{l}\text { Normed Chi- } \\
\text { square }\end{array}$ & $\begin{array}{l}\text { Lower limit: } 1.0 ; \\
\text { Upper limit: } 2.0 / 3.0 \text { or } \\
5.0\end{array}$ & 1,869 & GOOD FIT \\
\hline
\end{tabular}

Source: (Questionnaire results were processed with AMOS 23.0., 2020) 
Data Analysis and the Structural Model. Based on the results of the suitability of the model above, then the next step in the form of hypothesis testing using Structural Equation Modeling (SEM) can be done. Structural Equation Model (SEM) using the AMOS version 23 program. SEM is basically a collection of statistical techniques that allow the testing of a series of relatively complex relationships simultaneously (Ferdinand, 2002). Structural Equation Modeling This research can be seen in the following figure:

Figure 2. Structural Equation Modeling (SEM)

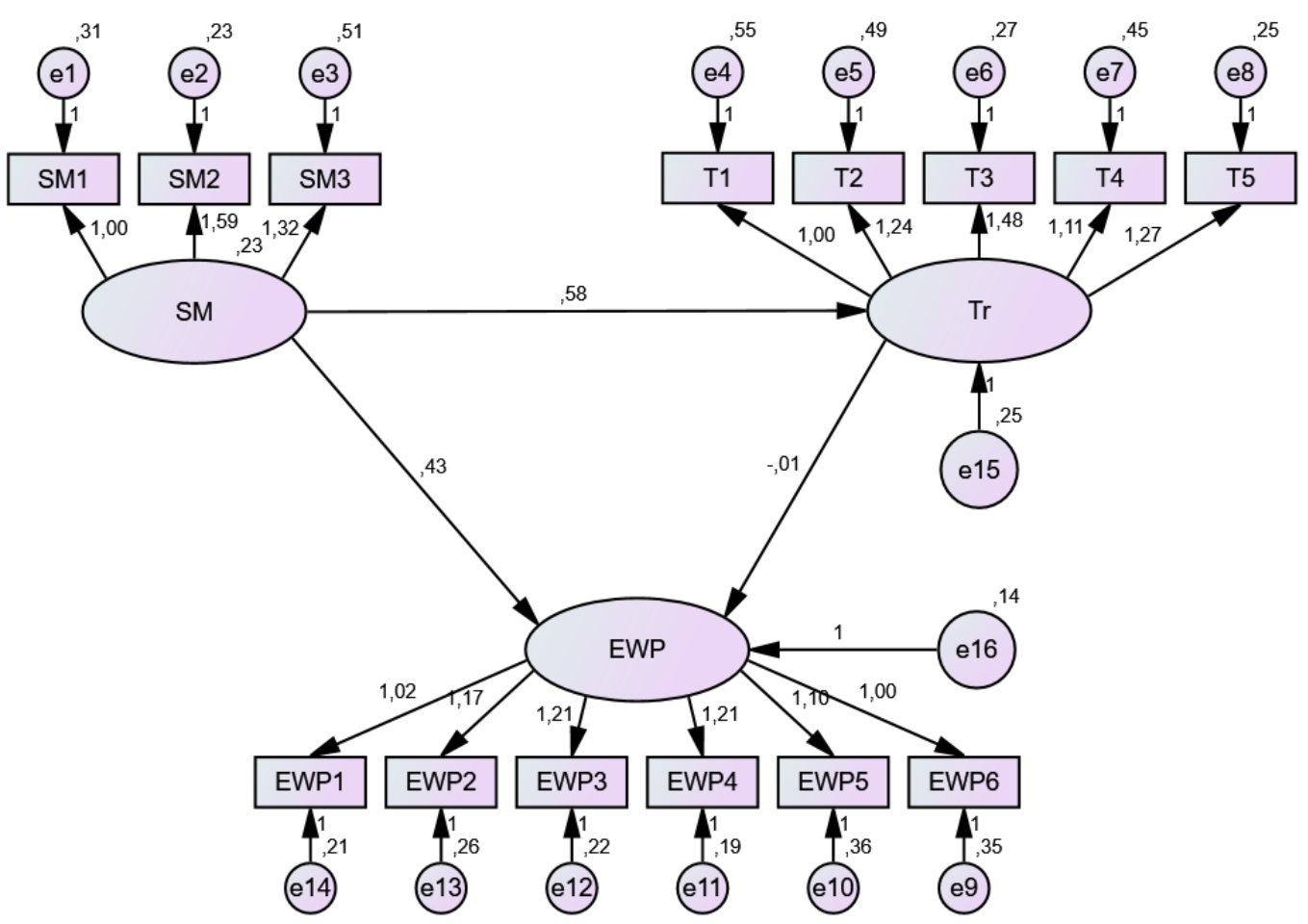

Source: (Results of processing with AMOS 23, 2020)

\section{THE RESULTS OF STATISTICAL TESTS AND DISCUSSION}

Results. Hypothesis testing is done by testing the C.R (t-value) whether greater than 1.96 or $\mathrm{p}$-value less than 0.05 . To compare the $\mathrm{p}$-value with the level of significance, based on the following conditions (Hair et al., 2013):

1. If the $p$-value $\leq 0.05$ then Ho is rejected and the research hypothesis is supported.

2. If the p-value > 0.05 then Ho fails to be rejected and the research hypothesis is not supported.

SEM test results can be seen in the following table: 
Table 6. Hypothesis Testing Results

\begin{tabular}{c|l|c|c|c|c}
\hline & \multicolumn{1}{|c|}{ Hypothesis } & Coefficient & $\boldsymbol{C . R}$ & p-value & Conclusion \\
\hline H1 & $\begin{array}{l}\text { There is an influence of Social } \\
\text { Media on Trust among } \\
\text { employees. }\end{array}$ & 0,582 & 3,483 & 0,000 & $\begin{array}{c}\text { HA1 } \\
\text { Accepted }\end{array}$ \\
\hline H2 & $\begin{array}{l}\text { There is an influence of Trust on } \\
\text { Employee Work Performance. }\end{array}$ & $-0,014$ & $-0,150$ & 0,880 & $\begin{array}{c}\text { HA2 } \\
\text { Rejected }\end{array}$ \\
\hline H3 & $\begin{array}{l}\text { There is an influence of Social } \\
\text { Media on Employee Work } \\
\text { Performance. }\end{array}$ & 0,432 & 2,987 & 0,003 & $\begin{array}{c}\text { HA3 } \\
\text { Accepted }\end{array}$ \\
\hline H4 & $\begin{array}{l}\text { Trust mediates the influence of } \\
\text { Social Media on Employee Work } \\
\text { Performance. }\end{array}$ & -0.008 & -0.145 & 0.884 & $\begin{array}{c}\text { HA4 } \\
\text { Rejected }\end{array}$ \\
\hline
\end{tabular}

Source: (Results of processing with AMOS 23, 2020)

Discussion. In testing hypothesis 1 , the results of data processing show that Social Media influences Trust, having a coefficient value of 0.582 which means that the higher the perception of Social Media, the higher the perception of Trust. Test results on the value of C.R (t-value) of 3.483 is greater than 1.96 or p-value of $0.000<0.05$ (alpha 5\%), it can be concluded statistically at a $95 \%$ confidence level there is a positive influence of Social Media on Trusts. Hypothesis 1 test results show that Social Media significantly influences Trust. Social media at work such as using social media to get work-related information, and using social media to maintain and strengthen communication with colleagues at work.

The results of this study support the results of previous studies conducted by (Cao et al., 2016) that the use of Enterprise Social Media (ESM) can create and strengthen social networks and interactions that can create trust among colleagues. The results of the study are also supported by studies of virtual teams and distributed work that find that trust is positively related to knowledge transfer (Chen and Hung, 2010). Thus, it can be concluded that if Social Media in the workplace is getting better, the Trust will be more positive.

The most dominant element of social media is the element 'I regularly use social media to maintain and strengthen communication with colleagues in my work' with a value of 1.59. This shows that the more social media used to communicate with colleagues in completing work, it will lead to increasing trust among employees.

In testing hypothesis 2 , the results of data processing show that Trust does not affect Employee Work Performance, has a coefficient of -0.014 . The test results on the CR value (t-value) of -0.150 smaller than 1.96 or p-value of $0.880>0.05$ (alpha 5\%), it can be concluded statistically at a $95 \%$ confidence level there is no positive influence of Trust on Employee Work Performance. Hypothesis 2 test results, showed that Trust does not significantly influence Employee Work Performance. The results of this study do not support the results of previous studies conducted by (Cao et al., 2016) that trust based on knowledge transfer on social media has increased the ability of employees to solve problems in an effective way, which in turn will improve employee work performance.

In testing hypothesis 3 , the results of data processing show that Social Media influences Employee Work Performance, has a coefficient value of 0.432 which means that 
the higher the perception of Social Media, the higher the perception of Employee Work Performance. Test results on the CR value (t-value) of 2.987 is greater than 1.96 or p-value of $0.003<0.05$ (alpha 5\%), it can be concluded statistically at a 95\% confidence level there is a positive influence of Social Media on Employee Work Performance. Hypothesis 3 test results, showed that Social Media significantly influence Employee Work Performance. Social media at work such as using social media to get work-related information, and using social media to maintain and strengthen communication with colleagues at work.

The results of this study support the results of previous studies conducted by (Leidner et al., 2010) that new employees perform better and faster after using ESM when building new relationships and facilitating quick tacit and transfer of explicit knowledge. Supported also by (Bennett et al., 2010) who found that, collective knowledge increases when using ESM thereby contributing to employee performance. Thus, it can be concluded that if Social Media in the workplace is getting better, then Employee Work Performance will be more positive.

The most dominant element of social media is the element 'I regularly use social media to maintain and strengthen communication with colleagues in my work' with a value of 1.59. This shows that the more social media is used to communicate with colleagues in completing work, it will lead to increasing employee performance. Employee performance will be increased by the use of social media. Employee performance is referred to as: better performance than accepted level, perform better than expected, try extra at work, make a lot of effort in carrying out work, trying to work as hard as possible, and the best quality of work. The most dominant element of Employee performance is the element 'I often put in extra effort in my work' and 'I intentionally expend a great deal of effort in carrying out my job' with a same value of 1.21.

In testing hypothesis 4 , the results of data processing show that the Trust does not mediate the influence of Social Media on Employee Work Performance, has a coefficient of -0.008 . Test results on the CR value (t-value) of -0.145 smaller than 1.96 or $p$-value of $0.884>0.05$ (alpha 5\%), it can be concluded statistically at a 95\% confidence level Trust does not mediate the positive influence of Social Media on Employee Work Performance. Hypothesis 4 test results, show that the Trust does not significantly mediate the influence of Social Media on Employee Work Performance. Although previous research has found that the use of Enterprise Social Media (ESM) can create and strengthen social networks and interactions that can create trust among colleagues (Fang and Chiu, 2010), and (Cao et al., 2016) found that trust based on knowledge transfer on social media has increased the ability of employees to solve problems in an effective way that will ultimately improve work performance, but the results of this study do not support. Means that the existence of Trust among employees does not strengthen the influence of Social Media on Employee Work Performance.

Then also testing whether the Trust variable can mediate the effect of Social Media variables on Employee Work Performance. The results obtained using the SOBEL test can be seen as below: 
Table 7. Sobel Test Results

\begin{tabular}{l|r|c|l|l}
\hline \multicolumn{1}{c|}{ Input: } & & T Statistic: & \multicolumn{1}{c}{ Std Error: } & \multicolumn{1}{c}{ p-value: } \\
\hline a 0.582 & Sobel test: & -0.14570582 & 0.0559209 & 0.88415363 \\
\hline b -0.014 & Aroian test: & -0.14006345 & 0.05817363 & 0.88860986 \\
\hline Sa 0.0167 & Goodman test: & -0.15209007 & 0.05357352 & 0.8791159 \\
\hline Sb 0.096 & \multicolumn{5}{|l}{} \\
\hline
\end{tabular}

Source: (Results of sobel test calculation, 2020)

Based on the results obtained, it is known that Trust does not mediate the influence of Social Media on Employee Performance with a CR value (t-value) of -0.145 meaning CR $<1.96$ which should be CR> 1.96 and a p-value of 0.884 means p-value $>0.05$ which should be a p-value $<0.05$. These results indicate that changes in the ups and downs of Trust's perception do not strengthen the influence of Social Media on Employee Work Performance.

\section{CONCLUSION}

Based on the results of the research, conclusions can be drawn as follows: (1). There is an influence of Social Media on Trust among employees. This shows that the more Social Media is used to communicate with colleagues in completing work, the more trust between employee increases. (2). There is no influence of Trust on Employee Work Performance. This shows that Trust among employees does not affect Employee Work Performance. This shows that employees' perceptions of virtual friends in the social media community always pay attention to their interests; pay attention to the situation; and care about what happens to him, it will not affect Employee Performance. So is the perception of employees who believe that virtual friends will do work with professionals; and trust in their competence, it will also not affect EmployeeWork Performance. (3). There is an influence of Social Media on Employee Work Performance. This shows that the more social media is used to communicate with colleagues in completing work, the more it improves employee Work performance. (4). Trusts do not mediate the influence of Social Media on Employee Work Performance. This shows that Trust among employees does not strengthen the influence of Social Media on Employee Work Performance.

Managerial Implications. Companies should continue to build networks in the workplace that connect experts in various social media so that it will improve employee performance effectively. Managers should encourage employees to use social media to gain knowledge and information. Managers continue to retain employees to communicate with colleagues using social media on a regular basis. Managers need to promote how communication on social media will build trust between employees in the workplace, so employees will continue to maintain and further strengthen that communication.

Suggestions for Further Research. This research was conducted with a limited number of samples and samples are employees of various industries. For further research, it can add the number of samples and with certain criteria, namely employees who have used social 
media in completing their work. Every job in every industry will be different in the use of social media. Therefore, in subsequent studies, samples were taken from employees in the same industry so that results can be more accurate. Addition of variables that mediate the influence of Social Media on Employee Performance, can be done. Such as knowledge transfer variables (Offong and Costello, 2017), network ties (Cao et al., 2016), or communication (Yu et al., 2018).

\section{REFERRENCE}

Alavi, M., and Leidner, D. (2001). "Review: Knowledge Management \& Knowledge Management Systems: Conceptual Foundations and Research Issues". MIS Quaterly, 25(1): 107-136. DOI: $10.2307 / 3250961$.

Andres, H.P., and Zmud, R.W. (2002). "A Contingency Approach to Software Project Coordination". Journal of Management Information System. Psychological Bulletin, 103(3): 411-423. http://dx.doi.org/10.1080/07421222.2002.11045695.

Anthony, R.N.M., and Govindarajan, M.V. (2001) Management Control System. $10^{\text {th }}$ Edition, Chicago, Illinois: Richard D. Irwin, Inc.

Bennett, E.E. (2014). "How An Intranet Provides Opportunities for Learning Organizational Culture: Implications for Virtual HRD”. Advanced In Developing Human Resources, 16(3): 296-319. DOI: 10.1177/1523422314532.

Cao, X., Guo, X., Vogel, D., and Zhang, X. (2016). "Exploring The influence of social media on employee of work Performance". Internet Research, 25(2): 529-545. https://doi.org/10.1108/IntR-11-2014-0299.

Chang, T.S., and Hsiao, W.H. (2014). "Time Spent on social networking sites understanding user behavior and social capital". Systems Research and Behavioral Sciences, 31(1): 102-114. DOI: 10.1002/sres.2169.

Chen, C., and Hung, S. (2010). “To Give or To Receive? Factors' Influencing Members Knowledge Sharing and Community Promotion in Professional Virtual Communities". Information and Management, 47(4): 226-236. DOI: 10.1016/j.im.2010.03.001.

De Jong, B.A., Dirks, K.T., and Gillespie, N. (2016). "Trust and Team Performance: A Meta Analysis of Main Effect, Moderators, Covariates". Journal of Applied Psychology, 101(8): 1134-1150.

DiMicco, J., Millen, D.R., Geyer, W., Dugan, C., Brownholtz, B., and Muller, M. (2008). "Motivations for social networking at work". Proceedings of The 2008 ACM Conference on Computer Supportive Cooperative Work (CSCW 08), New York: 711720.

Fang, Y., and Chiu, C. (2010). "In Justice We Trust: Exploring Knowledge Sharing Continuance Intentions in Virtual Communities of Practice". Computers in Human Behaviour, 26(2): 235-246. DOI: 10.1016/j.chb.2009.09.005.

Ferdinand, A. (2002). Structural Equation Modelling dalam Penelititan Manajemen. Badan Penerbit UNDIP, Semarang.

Hair, J.F., Anderson, R. E., and Black, W. C. (2014). Multivariate Data Analysis, Upper Saddle River, New Jersey: Prentice Hall Inc. 
Hariandja, M.T.E. (2004). Manajemen Sumber Daya Manusia, Pengadaan, Pengembangan, Pengkompensasian, dan Peningkatan Produktivitas Pegawai. PT. Grasindo, Jakarta.

Halabi, C.E., and Lussier, R.N. (2014). "A Model for Predicting a Small Firm Performance". Journal of Small Business and Enterprise Development. 21(1):4-25. DOI: 10.1108/JSBED-10-2013-0141.

Jackson, A., Yates, J.A., and Orlikowski, W. (2007). "Corporate blogging: building community through persistent digital talk". Proceeding of the $40^{\text {th }}$ Hawaii International Conference on Systems Sciences, Hawai, January 3-6.

Kankanhalli, A., Tan, B., and Wei, K. (2005). "Contributing Knowledge to Electronic Knowledge Repositories: An Empirical Investigation”. MIS Quaterly, 29(1); 113-143. DOI: $10.2307 / 25148670$.

Kuvaas, B. (2006). "Work Performance, Affective Commitment, and Work Motivation: The Roles of Pay Administration and Pay Level". Journal of Organizational Behavior, 27(3): 365-385. http://www.jstor.org/stable/4093933.

Kampkötter, P., Mohrenweiser, J., Sliwka, D. Steffes, S., and Wolter, S. (2016). “Measuring The Use of Human Resources Practices and Employee Attutudes: The Linked Personnel Panel". Evidence-Based HRM: A Global Forum of Empirical Scholarship, 4(2): 94-115.

Levin, D.Z., and Cross, R. (2004). "The Strength of Weak Ties You Can Trust: The Mediating Role of Trust in Effective Knowledge Transfer". Management Science, 50(11): 1477-1490. https://doi.org/10.1287/mnsc.1030.0136.

Leidner, D. Koch, H., and Gonzales, E. (2010). "Assimilating Generation Y IT New Hires Into USAA'S Workforce: The Role of Enterprise 2.0 System". MIS Quaterly Executive, 9(4): 229-242.

Lin, C. (2007). "To share or not to share: modeling tacit knowledge sharing, its mediators \& antecedents". Journal of Business Ethics, 70(4): 411-428. DOI: 10.1007/s10551-006-9119-0

McAfee, A.P. (2006). "Enterprise 2.0: the dawn of emergent collaboration". Engineering Management Review, 34(3): 38-38. DOI: 10.1109/emr.2006.261380.

North, M. (2010). "An Evaluation of Employees Attitudes toward Social Networking In The Workplace”. Issues In Information Systems, 11(1): 192-197.

Nilasari, B.M., Jasfar, F., and Wahyudi, A.S. (2019) "The Effect of Interactivity, Cost Effectiveness, and Compatibility on the Use of Social Media and its Implications for Organizational Performance". American Resaerch Journal of Business Management. $5(1): 1-17$.

Offong, G., O., and Costello, J. (2017). "Enterprise Social Media Impact on Human Resources Practices". Evidence-Based HRM: a Global Forum for Empirical Scholarship, 5(3): 328-343. https://doi.org/10.1108/EBHRM-06-2017-0031.

Pride, W., Hudges, R. J., and Kapoor, J. R. (2017) Foundation of Business. $5^{\text {th }}$ edition, Cengage Learning.

Parveen, F., Jaafar, N.I., and Ainin, S. (2016). "Social media's impact on organizational performance and entrepreneurial orientation in organizations". Management Decision, 54 (9): 2208-2234.

Sekaran, U., and Bougie, R. (2010) Research Methods for Business: Skill Building Approach. India: John Wiley \& Sons Ltd. Publication. 
Stasser, G., and Titus, W. (1985). "Pooling of Unshared Information Ingroup Decision Making: Biased Information Sampling During Discussion”. Journal of Personality and Social Psychology, 48(6): 1467-1478.

Smith, S.J. (2009). "The creative uses of Facebook as a tool for artistic collaboration". Proceedings of the electronic visualization and the arts (EVA 09). British Informatics Society Limited, London: 181-191. https://www.scienceopen.com/document_file/d3c4c537-04f7-46de-858066e7633a4feb/ScienceOpen/181_Smith.pdf.

Skinner, D., Dietz, G., and Weibel, A. (2014). "The Dark Side of Trust: When Trust Become A Poisoned Chalice", Organization, 21(2):206224.

Tika, P.M. (2010). Budaya Organisasi dan Peningkatan Kinerja. Perusahaan, Bumi Aksara, Jakarta.

Valenzuela, S., Park, N., and Kee, K.F. (2009). "Is there social capital in a social network site? Facebook use and college students' life satisfaction, trust, \& participation”. Journal of Computer-Mediated Communication, 14(4): 875-901). DOI: 10.1111/j.1083-6101.2009.01474.x.

Weibel, A., Den Hartog, D.N., Gillespie, N., Searle, R., Six, F., and Skinner, D. (2016). "How Do Control Impact Employee Trust in The Employer?" Human Resources Management, 55(3): 437-462.

Wasko, M. and Faraj, S. (2005). "Why Should I Share? Examining Social Capital and Knowledge Contribution in Electronic Network of Practice". MIS Quaterly, 29(1):3557.

Yu, L., Chao, X., Liu, Z., and Wang J. (2018). "Exploring The Effect of Social Media Overload on Job Performance". Information Technology and People, 31(6): 10911112. 